\title{
Pengaruh Inovasi Terbuka Terhadap Strategi Kewirausahaan
}

\author{
Nama : Adra Elviona Regina \\ Email : adraelvionaa@gmail.com
}

Entrepreneurial Orientation atau yang sering disebut dengan strategi kewirausahaan ini merupakan salah satu bentuk atau gaya yang mendukung suatu perubahan dan mendukung kegiatan yang berkaitan dengan eksploitasi berbagai bentuk inovasi, pengembangan produk atau layanan baru serta penciptaan nilai pelanggan yang unggul (Tajeddini, Martin, \& Ali, 2020). Hal ini juga sangat berhubungan dengan Open Innovation atau biasa disebut dengan inovasi terbuka yang merupakan suatu proses dimana sebuah perusahaan harus dapat menerima segala ide - ide inovatif yang berasal dari luar perusahaan (eksternal) sebagaimana mereka dapat menerima segala ide yang berasal dari dalam perusahaan (internal) (Guertler \& Sick, 2020). Selain itu dalam suatu perusahaan pasti terdapat Risk Governance atau biasa disebut dengan pengelolaan resiko yang merupakan suatu ketidakpastian konsekuensi yang akan didapatoleh perusahaan dan umumnya bersifat merugikan dari suatu kegiatan yang dianggap memiliki nilai khusus atau tersendiri (Kraub \& Bremmer, 2020).

Dalam jurnal Pratono (2018a) yang membuat kanjian tentang Open Innovation menjelaskan terdapat beberapa variabel yang digunakan untuk menjelaskan konsep ini yaitu, Social Capital Theory dan Dynamic Capability. Social Capital Theory sendiri secara singkat menjelaskan suatu hubungan jejaring bisnis yang dilakukan antar perusahaan satu sama lain dengan cara memberi nilai kerja sama antara individu satu dengan yang lainnya. Sedangkan pada Dynamic Capability atau biasa disebut dengan kemampuan dinamis ini lebih memfokuskan pada tindakan perusahaan yang saling ketergantungan dengan perusahaan lainnya sehingga dibutuhkan lebih lagi peran sumber daya didalamnya untuk mencapai kinerja yang lebih besar dan memenuhi tujuan mereka untuk memaksimalkan keuntungan (Pratono, Network structure and open innovation: the role of trust in product development, 2018a). Selanjutnya dalam jurnal Pratono (2018b) ini menjelaskan bahwa pengelolaan resiko terhadap UMKM dapat diukur melalui empat variable yang terdiri dari perilaku pengambilan resiko, kinerja perusahaan, kemampuan harga dan turbulensi teknologi informasi. Langkah tersebut diadopsi dari langkah subjektif yang dapat 
digunakan menjadi strategi penelitian untuk pengungkapan informasi keuangan dari UMKM (Pratono, Does firm performance increase with risk-taking behavior under information technological turbulence?: Empirical evidence from Indonesian SMEs, 2018b).

\section{Bibliography}

Guertler, M. R., \& Sick, N. (2020). Exploring the enabling effects of project management for SMEs in adopting open innovation - A framework for partner search and selection in open innovation projects. International Journal of Project Management. doi:https://doi.org/10.1016/j.ijproman.2020.06.007

Kraub, W., \& Bremmer, S. (2020). The role of place-based narratives of change in climate risk governance. Climate Risk Management, 28, 2-3.

Pratono, A. H. (2018a). Network structure and open innovation: the role of trust in product development. International Journal of Business Innovation and Research, 15(1), 44-61.

Pratono, A. H. (2018b). Does firm performance increase with risk-taking behavior under information technological turbulence?: Empirical evidence from Indonesian SMEs. The Journal of Risk Finance, 19(4), 361-378.

Tajeddini, K., Martin, E., \& Ali, A. (2020). Enhancing hospitality business performance: The role of entrepreneurial orientation and networking ties in a dynamic environment. International Journal of Hospitality Management, 90, 2-3. 